\title{
First report of the blue-stain of the wood caused by Ophiostoma pulvinisporum in Pinus chiapensis in Mexico
}

\author{
Montserrat Ramos-Vásquez ${ }^{1} \cdot$ Omar Alejandro Pérez-Vera $^{1}$ (D) $\cdot$ Silvia Edith García-Díaz ${ }^{1} \cdot$ Rodolfo Campos-Bolaños $^{1}$ • \\ José Tulio Méndez-Montiel ${ }^{1}$
}

Received: 21 January 2019 / Accepted: 1 March 2019 /Published online: 15 March 2019

(C) Società Italiana di Patologia Vegetale (S.I.Pa.V.) 2019

Keywords Blue-stain $\cdot$ Mexico $\cdot$ Ophiostoma pulvinisporum $\cdot$ PCR $\cdot$ White pine

White pine or Acalocote [Pinus chiapensis (Mart.) Andresen] is an endemic species from Mexico that has been used in commercial forest plantations. In September 2014, pine wood samples with symptoms of damage by Ips calligraphus Germar and fungal blue stain were collected in Mazolapa, Hueytamalco, Puebla. The wood contained perithecia with dark globose bases, 186-197 $\mu \mathrm{m}$ in diam., ornamented with aseptate hyphae, $70 \times 1.8 \mu \mathrm{m}$. Perithecial necks were dark brown, 980-984 $\mu \mathrm{m}$ long, 44-50 $\mu \mathrm{m}$ wide at base, 19$24 \mu \mathrm{m}$ wide at the apex. Ostiolar hyphae were absent and asci not observed. Ascospores were hyaline, aseptate, pillowshape, 3.8-4.3 $\times 1.7-2.2 \mu \mathrm{m}$. Small pieces of wood were surface disinfected for $1 \mathrm{~min}$, rinsed in sterile distilled water, and plated onto Malt Extract Agar (MEA). A fungus was isolated whose colonies were initially light gray at 10 days but turned dark gray with age. A reference specimen (UCH-DCF303) was deposited in the herbarium of the Forest Sciences Division of the Autonomous University of Chapingo, Texcoco, Mexico. Amplification of ITS was carried out using primers ITS4 and ITS5 (White et al. 1990). The PCR product (479 bp) was sequenced and deposited in GenBank (accession No. MK382983). The obtained sequence showed 99\% similarity to the ex-type sequence of Ophiostoma pulvinisporum
X. D. Zhou \& M. J. Wingfield, (AY546714, isolate CMW9022). Based on morphological and molecular characteristics, the fungus observed on Pinus chiapensis was identified as Ophiostoma pulvinisporum. O. pulvinisporum was described from galleries of bark beetles in Pinus pseudostrobus and $P$. maximinoi in México. It has also been found in P. contorta in Canada (Zhou et al. 2004). This is the first report of this fungus on Pinus chiapensis in Mexico, extending the host range of the fungus and vector.

\section{References}

White TJ, Bruns T, Lee S, Taylor J (1990) Amplification and direct sequencing of fungal ribosomal RNA genes for phylogenetics. In: Innis MA, Gelfand DH, Sninsky JJ, White TJ (eds) PCR protocols: a guide to methods and applications. Academic Press, San Diego, pp 315-322

Zhou X, De Beer ZW, Cibrián TD, Wingfield B, Wingfield MJ (2004) Characterisation of Ophiostoma species associated with pine bark beetles from Mexico, including O. pulvinisporum sp. nov. Mycol Res 108:690-698

Publisher's note Springer Nature remains neutral with regard to jurisdictional claims in published maps and institutional affiliations.

Omar Alejandro Pérez-Vera

oalejandrovera@gmail.com

División de Ciencias Forestales (Departamento de Ecología y Silvicultura), Universidad Autónoma Chapingo, Km 38.5 Carretera México-Texcoco, Chapingo, 56230 Texcoco, Estado de México, Mexico 